\author{
報文 \\ 玄米のいわゆる dietary fiber によるコレステロール； \\ トリグリセライド上昇抑制作用 \\ 鈴 木 雅子 \\ 福山市立女子短期大学家政科
}

\title{
Repressive Effect of Dietary Fiber Fractions in Unpolished Rice on the Increase in Cholesterol and Triglyceride
}

\author{
Masako SUZUKI \\ Department of Domestic Science, Fukuyama City \\ Women's Junior College, Fukuyama
}

\begin{abstract}
Ten healthy adult males (20-25 years old) who ingested in sugar under $30 \mathrm{~g} /$ day and drank no alcohol, were divided into two groups which were essentially the same in the age, body weight and height. During an experimental period of 10 days group 1 was fed unpolished rice and group 2 polished rice as staple food, and both groups were given $50 \mathrm{~g}$ of sugar every day and 2, 520.2 kcal/day as energy intake. Then the repressive effect of dietary fibers contained in unpolished rice was examined on an increase in serum level of cholesterol and triglyceride under these experimental conditions. The following results were obtained.

1) Serum total cholesterol was within a normal range in group 1 at 5 days of experiment and at the end of the experimental period. In group 2 it increased to 202.8 and $262.4 \mathrm{mg} / 100 \mathrm{ml}$ (that is 1.4 and 1.8 times, respectively, as high as the pre-experimental level) at 5 and 10 days, respectively, of experiment.

2) The cholesterol which had increased particularly in level in the group of polished rice was proved to be total-cholesterol-HDL-cholesterol (LDL + VLDL + other lipoprotein-cholesterol), which was regarded as one of the important etiological factors of arteriosclerosis.

3) The serum triglyceride level at the end of the experiment was $112.4 \mathrm{mg} / 100 \mathrm{ml}$ (gain $14.2 \mathrm{mg} /$ $100 \mathrm{ml}$ ) in group 1 and $132.4 \mathrm{mg} / 100 \mathrm{ml}$ (gain $21.6 \mathrm{mg} / 100 \mathrm{ml}$ ) in group 2 . It was within a normal range in both groups. But in the group 2 it increased higher than that of group 1.

4) Accordingly, these experimental results showed to demonstrate the repressive effect of dietary fibers on an increase in level of serum cholesterol and triglyceride.
\end{abstract}

(Received February 2, 1981)

近年, 食物中の非栄䧳的食品成分, いわゆる食物緎 維, dietary fiber (人間の消化醉素で消化されない食物 中の難消化性成分，以下 $\mathrm{DF}^{122)}$ ) を摄取させることによ り，各種疾病の予防を行ならことができるとの報告がな されている2) 。

とくにこれら DFは，血清脂質の減少に有効であり， 動脈硬化症予防に効果的であるとされている7) 11)。 一般に血清コレステロール，トリグリセライドの増加

\footnotetext{
千720 福山市本庄町 1750
}

は，動脈硬化症の進展に大空く関与する因子として考え られているが(12) 17)，これらの增加には砂煻の過剩搷取 などの食生活を原因とする報告が多くなされている。

すなわち，血清トリクリヒライドの上昇に, 砂糖の過 剩摃取が関連するとしたものに Macdonard ら ${ }^{18)}$, 他の 報告19) 33) があり，血清コレステロール上㫒との関連を 検討したるのに Winitz ${ }^{34)}$, Groen ${ }^{35)}$ らの報告がある。 ただ，血清コレステロールについては変化しないと した報告1820222336) もあり，現在まだ統一された見解はみ られていない。 
最近のわが国の砂糖消費量は，食生活の変化により 10 年前の約 2.5 倍となり ${ }^{37)}$, このうちの $80 \%$ は輸入 に賴っており，年間輸入額は 1,500 億円にものぼるとさ れている39)。

逆に，DF 摄取量は年々減少し，このよらな傾向はと

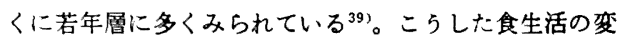
化は大腸癌 ${ }^{40)}$, 動脈硬化症など多くの成人病発症の原因 の一つとなっているのではないかと考えられる。

今回，食生活のあり方と血清脂質增減との関連性，增 減に及ぼす DF の作用を明確に把握するために，年龄 20〜25 藏の健康な男子を対象として，これに毎日 $50 \mathrm{~g}$ の仯慒を掑取させ，上昇する血清淞コレステロール（以 下 TC), HDL-コレステロール (以下 HDL-C), TCHDL-C，およびトリクリセライド (以下 TG) を， DF を掑取させることにより，抑制させる実験を試みたので 報告する。

\section{実 験 方 法}

\section{1. 対象者および実験期間}

対象者は，福山市内の企業においてデスクワークを主 務とする職業につき，害生活を行なっている健康な年 柃 20 25 歳の成人男子 5 名ずつの 2 集団, 計 10 名で ある。この 10 名は，健康診断により健康状態に異常が 地められず，血清脂質も正常值内にあるものであった。 この 10 名艺選出するにあたっては，まず多数の健康者 の日常の食生活を調へ，砂糖の摄取量が 1 日平均 $30 \mathrm{~g}$ 以下，フルコール摂取を行なわないるのを選んた。っつぎ にこれらのもののなかから，年昤が一定，体位がほほ 定する 2 人を選び，これを二つの集団の 1 名ずつに充当 させ，同羔な操作をくり返して，5名ずつの二つの集团 を作った。このようにしてできあがった二つの集団は， 年路, 体位, 職業がほぼ一定とい5㯕成をしつ内容であ った。

なお、これら対象者の㝜験開始前 1 週間における栄盖 掑取量の平均を求めたところ，対象者の平均値は，20〜 25 葴の男性が摂取すべき栄養量を下まわる状態がしめ されていた。

主食は白米であった。

対象者遙択の際，砂搪とアルコール摂取者に制限を加 光たのは，平常これらの掑取が多い場合，対象者がすて に，その影響を受けているかもしれぬといら可能性を排 除するためである。

実験期間は，昭和55年 8 月 1 日から10日までの 10 日 間であった。

\section{2. 食物楼維の定昌}

DF は一般には，人間の消化醏素で消化されない食物 中の難消化性成分 ${ }^{122)}$ とされている。今回実験で使用し
た DFは，玄米の果種皮，肧芽部に含有されるもの，お よび白米，副食中の食品に含有されるむのであった。 玄米は果種皮，肧 (阫芽)，肧乳の 3 部から成り，その $w \%$ は果種皮（糊粉層を含む） $5 \sim 6 \%$, 肧 $2 \sim 3 \%$, 肧 劧 $91 \sim 92 \%$ とされている。

玄米中の DF の定量には Southgate 法位を用いた。 たたしこの方法では，沷粉分解にタカジフスターゼを用 いているが,これにはセルラーゼの混入があると考えら れ，定畾値が高くなることから，七ルラーゼを含有しな いクルコフミラーぜを用いた42)。

すなわち玄米 $10 \mathrm{~g}$ を粉末とし， $n$-へキサンで脱脂

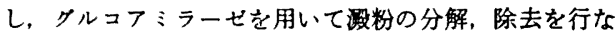

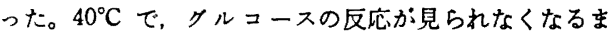
で継続した。反応に要した時間は 26 時間であった。こ の後上澄を除き，残渣の DF 部分を水洗し，75\%の大 タノールを加え，さらに 1 時間煮沸して遊離の糖の除去 を行なった。ついで，各種の浱度の異なる硫酸を加え， 分別定量により，人ミセルロース，七ルロース、リクニ ン区分を求めた。同様にして, 白米中の DF 量を求め た。

副食中の DF 量については, Van Soest ${ }^{43)}$,Southgate ${ }^{44)}$, 森 ${ }^{45)}$ らの分析値から、これらから明確でないものについ ては実際に分析を行なった ${ }^{41) 。 ~}$

本実験において分析を行なったDF含有食品は，ね き，にら，青じ，れんこん，さつまいもであり，分析 値を Table 1 にしめした。

以上のよらな方法で，実験期間中における対象者の平 均 DF 摂取量 ( $\mathrm{g} /$ day) を求めた。

\section{3. 対象者の DF 摄取方法}

対象者はいずれも社員寮において提供される朝，夕食 を搷取しており，昼食は主として勤務先の社員食堂を利 用している。

そこで対象者の二つの集団において，調査期間中 1 集 団では主食を玄米, 他の 1 集団では白米とし, 副食は 2 集団ともまたく同じといら内容の食事を摄取してるら い実験を行なった。

なおこの際の玄米および白米の摂取量は，1人1日3 回で $300 \mathrm{~g}$ (1 食分 $100 \mathrm{~g}$ ) であり, 主食の容器を定め, これに正確にもりつけた。な拈事に際しては残菜を出 さぬよう，また定められた量より多く食したり，定めら れたもの以外食さぬよ5指运した。とくに啫好领料とし ての砂糖入りコーヒー, 红茶、ジュース，また甘い菓子 類などは，砂糖摂取量に譔差を生じることから，摄取せ ぬよら指示を行なった。

\section{4. 対象者の砂榙摄取方法}

対象者 1 人 1 日あたり $50 \mathrm{~g}$ の砂糖を摄取してるらっ た。方法としては，20 g を3食の副食の調味料として， 
Table 1. Dietary fiber content of vegetables.

(\% in dry matter)

\begin{tabular}{lcccrc}
\hline \multicolumn{1}{c}{ Vegetable name } & Hemicellulose & Cellulose & Lignin & DF & CF \\
\hline "Negi" (Welsh onion greens) & 3.9 & 11.2 & 1.4 & 16.5 & 11.6 \\
"Nira" (Allium tuberosum greens) & 3.2 & 9.8 & 0.9 & 13.9 & 10.2 \\
"Aoziso" (Beefsteak plant) & 4.1 & 12.1 & 1.8 & 18.0 & 13.4 \\
"Renkon" (to pare) (East Indian lotus) & 0.9 & 6.0 & 0.7 & 7.6 & 0.9 \\
"Satsumaimo" (to pare) (Sweet potato) & 1.4 & 7.6 & 1.8 & 10.8 & 0.8 \\
\hline
\end{tabular}

Table 2. Average of age, body height and weight in subjects.

\begin{tabular}{|c|c|c|c|c|c|c|}
\hline & \multicolumn{3}{|c|}{ Unpolished rice group } & \multicolumn{3}{|c|}{ Polished rice group } \\
\hline & Initial & Final & Gain & Initial & Final & Gain \\
\hline Age & 22.1 & & & 22.1 & & \\
\hline Height $(\mathrm{cm})$ & 161.7 & & & 161.5 & & \\
\hline Weight $(\mathrm{kg})$ & 57.4 & 58.3 & 0.9 & 57.2 & 58.8 & 1.6 \\
\hline
\end{tabular}

残り $30 \mathrm{~g}$ は朝食前に水道水（約 $200 \mathrm{~g}$ ) に混ぜて飲用し てもらった。たたし採血時においては，採血後领用し た。

5. 血清コレステロール，トリグリセライドの定量 玄米および白米集団において，実験開始前，実験開始 後 5 日目, 終了時の 10 日目の計 3 回, 早朝空腹時に採血 し、コレステロールおよびトリグリセライドの測定を行 なった。

TC については，一般に用いられている Kiliani 反応 によるZak らの方法 ${ }^{46)}$ をいた。HDL-C については， 福山医師会臨床唡査センターに測定を依頼した。測定方 法は Lipid Research Clinics Program に準じた。へパ リン・マンガン沈降法で出で HDL を回収し、オートフ ナライザー法 ${ }^{48)}$ によるものであった。

またこの際，実験者の測定した TC，TG 值が妥当な むのであるか否かを判定するために, 上記嘰関に 1 换体 の TC, TG 值の測定を依頼し, 测定値を実験者のそれ と比較した。下記はその比較値である。

$\begin{array}{ccr}\text { 測定内容 } & \text { 福山医師会臨床湌査センター 実験者 } \\ \mathrm{TC} & 234 \mathrm{mg} / \mathrm{dl} & 259 \mathrm{mg} / \mathrm{dl} \\ \mathrm{TG}^{49} & 109 \mathrm{mg} / \mathrm{dl} & 99 \mathrm{mg} / \mathrm{dl}\end{array}$

この比較値から実験者の測定値を妥当と判定し，以後 実験における測定値として使用した。

\section{6. 統計処理方法}

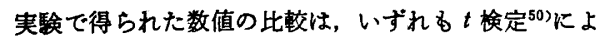
った。

\section{結果および考察}

\section{1. 対象者の平均年齢および体位}

対象者の実駼開始前における平均年龄, 体位小よで実 験終了後の体位は Table 2 にしめすとおりであった。

表によれば，実験開始後 10 日間において，立米集団 $0.9 \mathrm{~kg}$, 白米集団 $1.6 \mathrm{~kg}$ の体重增加がみられていた。 これは, 実験開始前と後の栄養撕取量の違いによるもの と考えられる。いずれにしても，10 日間にお!る增加 量としてはその変化が大であり,こうした変化をもたら

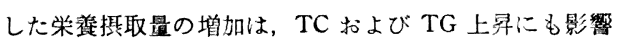
を及ぼしたものと考えられる。

\section{2. 玄米, 白米ならびに副食中の DF 盢}

対象者 1 人あたりが摂取した玄米 $(300 \mathrm{~g} / \mathrm{day})$ および 白米 $(300 \mathrm{~g} /$ day $)$ ならぴに副食中の DF 平均摂取量 (g/day) を Table 3 にしめした。

玄米集団と白米集団の総合 DF 恸取量を比䡆すると, 玄米集団は白米集団の約 3.4 倍の摂取量をし的してい た。

\section{3. 対象者の実験前，期間中における栄恙摂取量}

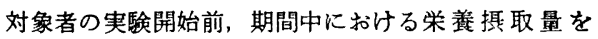
Table 4 にしめした。

表によれば対象者の栄養摂取量は，実験開始前に比べ 開始後は大幅に好鞋しておりこれは体重增加，また TC，TG を上䄯させる大きな要因の一つとなったもの と考えられる。

実験期間中における玄米集団と白米集団の差は, 主食 
Table 3. Amount of dietary fiber contained in rice and side dishes.

\begin{tabular}{lcc}
\hline & Unpolished rice group & Polished rice group \\
\hline Total dietary fiber in rice $(\%)$ & 8.9 & 1.1 \\
\hline Hemicellulose $(\%)$ & 5.1 & 0.8 \\
Cellulose $(\%)$ & 2.9 & 0.2 \\
Lignin $(\%)$ & 0.9 & 0.1 \\
\hline Total dietary fiber in side dishes (g/day) & 6.6 & 6.6 \\
\hline Total dietary fiber in diets (g/day) & 33.3 & 9.9 \\
\hline
\end{tabular}

Table 4. Average intake of nutrition by subjects.

\begin{tabular}{lccc} 
& Before the experiment & During the experiment & Gain in the experiment \\
\hline Total energy (kcal/day) & $1,992.4$ & $2,520.2$ & 527.8 \\
Protein (g/day) & 60.4 & 87.9 & 27.5 \\
Carbohydrate (g/day) & 322.6 & 390.2 & 67.6 \\
Lipid (g/day) & 46.4 & 62.3 & 15.9 \\
\hline
\end{tabular}

Table 5. Change in serum cholesterol and serum triglyceride during the experimental period.

(mg/100 ml) (Mean \pm S.D.)

\begin{tabular}{|c|c|c|c|c|c|c|c|c|}
\hline & \multicolumn{2}{|c|}{0 day (Initial) } & \multicolumn{2}{|c|}{5 days } & \multicolumn{2}{|c|}{10 days (Final) } & \multicolumn{2}{|c|}{ Gain } \\
\hline & $\begin{array}{l}\text { Unpol- } \\
\text { ished } \\
\text { rice } \\
\text { group }\end{array}$ & $\begin{array}{l}\text { Polished } \\
\text { rice } \\
\text { group }\end{array}$ & $\begin{array}{l}\text { Unpol- } \\
\text { ished } \\
\text { rice } \\
\text { group }\end{array}$ & $\begin{array}{l}\text { Polished } \\
\text { rice } \\
\text { group }\end{array}$ & $\begin{array}{l}\text { Unpol- } \\
\text { ished } \\
\text { rice } \\
\text { group }\end{array}$ & $\begin{array}{l}\text { Polished } \\
\text { rice } \\
\text { group }\end{array}$ & $\begin{array}{l}\text { Unpol- } \\
\text { ished } \\
\text { rice } \\
\text { group }\end{array}$ & $\begin{array}{l}\text { Polished } \\
\text { rice } \\
\text { group }\end{array}$ \\
\hline $\begin{array}{l}\text { Total } \\
\text { c'rolesterol }\end{array}$ & $\begin{array}{l}138.6 \\
\pm 23.9\end{array}$ & $\begin{array}{l}145.8 \\
\pm 21.8\end{array}$ & $\begin{array}{l}149.6 \\
\pm 22.6\end{array}$ & $\begin{array}{l}202.8 \\
\pm 30.6\end{array}$ & $\begin{array}{l}151.3 \\
\pm 22.4\end{array}$ & $\begin{array}{l}262.4 \\
\quad \pm 20.3\end{array}$ & $\begin{array}{l}12.7 \\
\quad \pm 2.4\end{array}$ & $\begin{array}{l}116.6 \\
\pm 19.6^{* *}\end{array}$ \\
\hline $\begin{array}{l}\text { HDL } \\
\text { cholesterol }\end{array}$ & $\begin{array}{l}50.2 \\
\quad \pm 6.8\end{array}$ & $\begin{array}{l}51.3 \\
\quad \pm 5.4\end{array}$ & $\begin{array}{l}52.9 \\
\quad \pm 7.2\end{array}$ & $\begin{array}{l}52.6 \\
\quad \pm 6.4\end{array}$ & $\begin{array}{l}54.3 \\
\quad \pm 4.8\end{array}$ & $\begin{array}{l}50.6 \\
\quad \pm 5.7\end{array}$ & $\begin{array}{l}4.2 \\
\pm 1.6\end{array}$ & $\begin{array}{l}-0.7 \\
\quad \pm 0.8^{* *}\end{array}$ \\
\hline $\begin{array}{l}\text { VLDL+LDL } \\
\text { cholesterol }\end{array}$ & $\begin{array}{l}88.4 \\
\quad \pm 11.4\end{array}$ & $\begin{array}{l}94.5 \\
\pm 12.4\end{array}$ & $\begin{array}{l}93.7 \\
\pm 19.4\end{array}$ & $\begin{array}{l}150.2 \\
\pm 21.4\end{array}$ & $\begin{array}{l}97.0 \\
\pm 6.4\end{array}$ & $\begin{array}{l}211.8 \\
\pm 17.4\end{array}$ & $\begin{array}{l}8.6 \\
\pm 0.7\end{array}$ & $\begin{array}{l}117.3 \\
\pm 20.6^{* *}\end{array}$ \\
\hline $\begin{array}{l}\text { Total } \\
\text { triglyceride }\end{array}$ & $\begin{array}{l}98.2 \\
\quad \pm 20.4\end{array}$ & $\begin{array}{l}110.8 \\
\pm 21.3\end{array}$ & $\begin{array}{l}110.1 \\
\pm 19.4\end{array}$ & $\begin{array}{l}121.6 \\
\pm 20.8\end{array}$ & $\begin{array}{l}112.4 \\
\pm 20.1\end{array}$ & $\begin{array}{l}132.4 \\
\pm 19.8\end{array}$ & $\begin{array}{l}14.2 \\
\quad \pm 1.9\end{array}$ & $\begin{array}{l}21.6 \\
\quad \pm 5.4^{* *}\end{array}$ \\
\hline
\end{tabular}

** Significantly different from unpolished rice group, $p<0.01$.

としての立米と白米の消化率 ${ }^{51}$ ，すなわち玄米 $90 \%$ ， 白米 $98 \%$ の差，ならびに玄米集団の DF 摂取量が白米 集団の 3.4 倍になることから生ずる，DF の栄㭚素吸收 阻害を考管して倹討する必要があると考えられる。しか し，こ礼ついては今回娭討を加えていないので，攝取 量としてのみあげておいたものである。
4. 実験期間中におけるコレステロール，トリグリセ ライドの变化

实驗開始前，開始後 5 日目，終了日の 10 日目における TC, HDL-C, TC-HDL-C (VLDL+LDL+その他のリ ポたん白質一C) および TGについて剆定した結果を Table 5 にしめした。

表によれば，玄米慗団はTCにおいて5 日後，実跧終 了時の 10 日後も正常の範团内にあったが，白米集団は 
5 日後 $202.8(\mathrm{mg} / 100 \mathrm{ml}$ ) (実倹開始前の 1.4 倍), 終了 時 $262.4(\mathrm{mg} / 100 \mathrm{ml}$ ) (実哙開始前の 1.8 倍) となって いた。

この際とくに上㫒したのは TC-HDL-C であり、これ は5 日後 1.6 倍，終了時 2.2 倍となっていた。一般に HDL-C と VLDL+LDL-C の比は， 50 対 $150 く ら い$ が平均的だといわれるが，VLDL + LDL-C の低下は，い わゆる動脈硬化指数（VLDL+LDL-C/HDL-C）を低下 させることから，動脈硬化症の発症防止に有効であると 考えられる。この動脈硬化指数の低下には，食生活が関 連するのではないかと考えられるが52) 54), その他の要 素については明確ではない。

また、これらニレステロール上㫒に影啎を及ぼす要因 の一つに，砂糖の過剩摄取があると考えられる。しかし 今回の実験における砂糖摂取量は $50(\mathrm{~g} / \mathrm{day})$ であり、こ れがこの実験におけるコレステロールの急激な上㫒をも たらした直接の原因とは考えにくい。上昇をらながした 強力な原因となったのは，むしろ Table 2 にしめした 実験期間中の栄養摄取量の增加と考えられる。

白米集団においては，栄度撕取量の増加によりコレス テロールの急上昇がみられ，玄米集団においては玄米の 消化吸叹害が低いことから，白米集団に比べ栄養摄取量 の增加が少なく、さらに増加した DF が栄養吸収を抑え るとともに, ニレステロール上昇をる抑制したといら相 乗的効果か，短期間においてこのよ5な大きな上昇差を 生じさせたのではないかと考えられる。

また，玄米の TC 抑制作用についての Vijayagopalan ら5556)のラットによる実験結果では，その有効成分はウ ロン酸を含む多糖類であるとし，綾野ら ${ }^{57)}$ の同しくラッ トによる結果では，へミセルロース区分であろらと報告 されている。

TC 上昇抑制については， DF の内容的娭討を加えつ つ、さらに実耠条件を変化させ多くのデータを集約して ゆく必要があると考える。

TGについては，実験終了時において玄米集団では $14.2(\mathrm{mg} / 100 \mathrm{ml})$, 白米集団では $21.6(\mathrm{mg} / 100 \mathrm{ml})$ の 上昇がみられた。これらはいずれも正常の範囲内におけ る変化であったが，玄米集団におけるより白米集団のほ らがその上昇度合が大であり，実験終了時 $p<0.01$ にお いて二つの集団の上昇差に有意差がみられていた。

以上の結果を紛合すると，今回の実験条件は対象者が 20 25 歳の男性, 日常の砂糖摂取量が 30 (g/day) 以下,

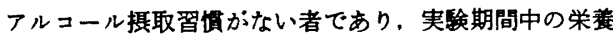
掑取量が実験前と比較して大幅に好転していたという限 定されたすのではあったが，玄米中の食物瀻維による血 清コレステロール，トリグリセライド上昇抑制効果が認 められたと考えられる。
しかし、こらした抑制作用が普遍的条件においても認 められるか否か，今後実験を続け検討を加えてゆきたい と考える。

$$
\text { 要約 }
$$

日常の砂糖掑取量か：30(g/day) 以下, アルコールの摄 取習惯のない健康な成人男子（年踰 20 25 歳）10 名 を，体位がほほ同じょうな 2 集団にわけ，1 集団は 10 日の実験期間中の主食を玄米, 他の集団は白米とし，こ の 2 集団の対象者全員に砂糖を毎日 $50(\mathrm{~g} / \mathrm{day})$ 拱取さ せた。栄荃摂取量は央験開始前の総カロリー 1,992.2 (kcal/day) を実験中 $2,520.2(\mathrm{kcal} / \mathrm{day})$ とした。こ した条件下で上昇する TC，TG に対する食品中，とく に玄米中の食物瀻維の抑制作用について検討し，次のよ らな結果を得た。

1） 2 集団の食物緎維揸取量は，1 人平均立米集団で 33. 3( $\mathrm{g} / \mathrm{day})$ ，白米集団で $9.9(\mathrm{~g} / \mathrm{day})$ であった。この らち玄米のみからは26.7(g/day)，白米のみからは 3.3 （g/day）を摂取していた。

2）血清総コレステロールは，実験開始前玄米集団 $138.6(\mathrm{mg} / 100 \mathrm{ml})$, 白米集団 $145.8(\mathrm{mg} / 100 \mathrm{ml})$ であ ったが，5 日後玄米集団では $11.0(\mathrm{mg} / 100 \mathrm{ml})$ の上昇 があったのに対し，白米集団は $116.6(\mathrm{mg} / 100 \mathrm{ml})$ の上 昇をしめした。

3）白米集団においてとくに上昇したコレステロール は, 動脈硬化症発症の原因の一つとされる，TC-HDL-C であった。

4）トリクリセライドについては，実駼終了時にお いて，玄米集団では $14.2(\mathrm{mg} / 100 \mathrm{ml})$ ，白米集団では $21.6(\mathrm{mg} / 100 \mathrm{ml})$ の上䄯がみられた。これらはいずれ も正常値の範囲内に打ける変化であったが，玄米集団に おけるトリクリセライドのほうが白米集団よりその上年 度合が低かった。

5）以上の実験結果より，玄米中の食物緎維による血 清コレステロール，トリクリセライドの上昇抑制作用が 認められた。

本実験を行ならにあたり，たいへんなご協力をいたた きました国広告社代表取締役鉿木 毅氏, 調理員田 中朋子、藤井景子氏，また被験者の方々に厚くお礼申し あげます。

また血清コレステロール，トリクリセライド測定に際 しご尽力いたたいた福山医師会臨床検査センター検査室 佐藤由美子氏に対しお礼申しあげます。

\section{文献}

1) Trowell, H.C., Southgate, D.A., Wolever, T. M.S., Leeds, A.R., Grassull, M. and Jenkins, 
D.J.A. : Lancet, 1, 967 (1976)

2) 桐山修八：化学々生物, 18, 95(1980)

3) Walker, A.R.P. : S. Afr. Med. J., 21, 590 (1947)

4) Cleave, T.L. : J. Roy. Nav. Serv., 42, 55 (1956)

5) Burkitt, D.P. : J. Surg., 58, 695 (1971)

6) Trowell, H.C. : Diabetes, 24, 762 (1975)

7) Shurpalekar, K.S., Doraiscwamy, T.R., Sundaravalli, O.E. and Rao, N.N. : Nature, 232, 554 (1971)

8) Jenkins, D.J.A., Hill, M.S. and Cummings, J. H. : Am. J. Clin. Nutr., 28, 1408 (1975)

9) Cummings, J.H., Hill, M.J., Jenkins, D.J.A., Pearson, J.R. and Wiggings, H.S. : $A m$. J. Clin. Nutr., 29, 1468 (1976)

10) Jenkins, D.J.A., Reynolds, D., Leeds, A.R., Waller, A.L. and Cummings, J.H. : Am. J. Clin. Nutr., 32, 2430 (1979)

11) Anderson, J.W., Chen, W.J.L. and Sieling, B. : Metabolism, 29, 551 (1980)

12) Keys, A. : Atherosclerosis, 20, 118 (1953)

13) Lyon, T.P., Yankley, A., Gofman, J.W. and Strisower, B. : Calif. Med., 84, 325 (1956)

14) Hegsted, D.M., McGandy, R.B., Myers, M.L. and Stare, F.J.: Am. J. Clin. Nutr., 17, 281 (1965)

15) Keys, A., Anderson, J.T. and Grande, F. : Metabolism, 14, 747 (1965)

16) Bilrenbaum, M.L., Green, D.P., Florin, A., Fleishchman, A.I. and Caldwell, A.B. : Circulation, 31-32, Suppl. 2, 3 (1965)

17) Leren, P.: Acta Med. Scand. Suppl., 466, 1 (1966)

18) Macdonald, I. and Braithwaite, D.M. : Clin. Sci., 27, 23 (1964)

19) Kuo, P.T. and Basset, D.R. : Ann. Int. Med., 62, $1192(1965)$

20）五島雄一郎, 中村治雄, 堀 貞昭, 後藤正博 : 日 老医誌，3，295 (1966)

21) Kaufmann, N.A., Poznaski, R., Blondheim, S.H. and Stein, Y. : Am. J. Clin. Nutr., 18, 261 (1966)

22) Kuo, T.P., Feng, L., Cohen, N., Fitts, W.T. and Miller, L.D. : Am. J. Clin. Nutr., 20, 116 (1967)

23) Kaufmann, N.A., Poznanski, R., Blondheim, S.H. and Stein, Y. : Am. J. Clin. Nutr., 20, 131 (1967)

24) Anderson, J.T. : Am. J. Clin. Nulr., 20, 168 (1967)

25) Akinyanju, P. and Yudkin, J. : Nature, 214, 426 (1967)

26) Staub, H.W. and Thiessen, R., Jr. : J. Nutr., 95, 633 (1968)

27) Webb, W., Nestlel, P.J., Foxman, C. and Lynch, A. : Nutr. Rep. Int., 1, 189 (1970)

28) Naismith, D.J. : Proc. Nutr. Soc., 30, 259 (1971)

29) Naismith, D.J. and Khan, N.A. : Proc. Nutr.
Soc., 30, 12A (1971)

30) Bruckdorfer, K.R., Kang, S.S. and Yudkin, J. : Proc. Nutr. Soc., 31, IIA (1971)

31）平沢芙美子，下垣玲子，時田昭枝，深川卯子，小 池五郎, 吉川春寿: 栄養之食粞, 25, 328 (1972)

32) Michaelis, O.: J. Nutr., 104, 1597 (1974)

33) Thompson, R.G. : Science, 206, 838 (1979)

34) Winitz, M., Graff, J. and Seedman, D.A. : Arch. Biochem. Biophys., 108, 576 (1964)

35) Groen, J.J., Balogh, M., Yaron, E. and Cohen, A.M. : Am. J. Clin. Nutr. 19, 46 (1966)

36) Grande, F., Anderson, J.T. and Keyes, A. : Am. J. Clin. Nutr., 27, 1043 (1974)

37）農林省官房調査課（編）：昭和 52 年度食糧需給表 (1979)，農林統計協会

38）吉田勉：食品添加物，40（1979），芽ばえ社（東 京）

39) 鉿木雅子: 栄爰学雑誌, 38, 123 (1980)

40) Burkitt, D.P. and Painter, N.S. : Lancet, 2, 1408 (1972)

41) Southgate, D.A.T. : J. Sci. Food. Agric., 20, 331 (1969)

42）森 文平：日本栄養・食糧学会関東支部総会講演 要旨集, 8 (1979)

43) Van Soest, P.J. : J.A.O.A.C., 46, 825 (1963)

44) Southgate, D.A.T., Bailey, B., Collinson, E. and Waker, A.F. : J. Human Nutr., 30, 303 (1976)

45）森 文平：臨床栄養， 57，636（1980）

46) Zak, B., Dikenman, R.C., White, E.G., Burnet, H. and Cheoneg, P.J. : Am. J. Clin. Pathol., 24, 1307 (1954)

47) Lipid Research Commission (ed.) : Lipid Research Clinics Program Manual Laboratory Operation, Vol. 1, 75-628 (1974), OHEW Publication No. (NIH)

48) Levine, J.R. and Zak, B. : Clin. Clim. Acta, 10, 381 (1964)

49) Fletcher, M.J. : Clin. Chein. Acto, 22, 393 (1968)

50) 谈中忠郎, 石川栄助：新統計学，221 (1977)，椇 書店 (東京)

51) 福場博保: 米と飯の科学, 29 (1977), 財団法人 全国米穀配給協会

52) Blum, C.R.:J. Clin. Invest., 60, 795 (1977)

53) Shepherd, J. : J. Clin. Invest., 61, 1582 (1978)

54) Miettinen, T.A. : Atherosclerosis, 311 (1980), Springer Verlag (New York)

55) Vijayagopalan, P. and Kurup, P.A. : Atherosclerosis, 11, 257 (1970)

56) Vijayagopalan, P. and Kurup, P.A. : Atherosclerosis, 15, 215 (1972)

57）綾野雄幸, 太田冨貴雄, 渡辺幸雄, 三田浩三 : 栄 䖯と食糧，33，283（1980）

(昭和 56 年 2 月 2 日受理) 